International Review of Social History 45 (2000), pp. 19-46

(C) 2000 Internationaal Instituut voor Sociale Geschiedenis

\title{
Negotiating a Living: Essex Pauper Letters from London, $1800-1834$
}

\author{
THOMAS SOKOLL
}

Research undertaken over the last generation has greatly enhanced our understanding of the survival strategies of the labouring poor in early modern Europe. Under economic conditions where poverty was endemic, most families were forced to take to various forms of work and to draw on whatever forms of income were available. Whether among small peasants, proto-industrial producers, landless labourers or casual workers, their mere subsistence depended on the effort of as many family members as possible. Women's and children's work were the norm well into the nineteenth century, and their contribution to the family income greater than previously assumed. There were, nevertheless, many who could not make ends meet. The reasons for which people had to turn to others for help are legion: structural, cyclical or seasonal unemployment and underemployment; insufficient earnings and debts; illness and accidents; death within the family. A lot of assistance was informal and went through networks of kinship, neighbourhood and local community. Friendly societies provided rudimentary forms of collectively-organized support. Some state or municipal agencies supplying poor relief and charitable institutions offered assistance of various types, but most of it was meagre and combined with social control of the clients. It is no wonder, therefore, that many people took to begging, prostitution or petty crime. ${ }^{I}$

While there is ample evidence, then, that the labouring poor were forced to engage in a broad spectrum of activities and to draw on numerous resources in order to gain their subsistence, the strategic decisions involved in this remain less well understood. Strategic action implies choice. Ideally, it involves the rational choice between alternative opportunities and the assessment of the pros and cons of a particular course of action against other possible courses. It also involves a notion of the possible consequences of the alternative options to hand. But considerations of that kind are scarcely documented for labouring people before the middle of the nineteenth

1. Jean-Pierre Gutton, La société et les pauvres en Europe (XIVe-XVIIIe siècles) (Paris, 1974); Olwen Hufton, The Poor of Eighteenth-Century France 1750-1789 (Oxford, 1974); Catharina Lis and Hugo Soly, Poverty and Capitalism in Pre-Industrial Europe, rev. edn (Brighton, 1982); Volker Hunecke, "Überlegungen zur Geschichte der Armut im vorindustriellen Europa", Geschichte und Gesellschaft, 9 (1983), pp. 480-512; Stuart Woolf, The Poor in Western Europe in the Eighteenth and Nineteenth Centuries (London, 1986); Marco D.H. van Leeuwen, "Logic of Charity: Poor Relief in Preindustrial Europe", Journal of Interdisciplinary History, 24 (1994), pp. 589-613; Robert Jütte, Poverty and Deviance in Early Moderm Europe (Cambridge, 1994). 
century. For example, it is only from then on that working-class autobiographies survive in significant numbers. Likewise, the testimonies of the poor, as recorded in the works of social investigators such as Henry Mayhew or Frédéric Le Play, date only from that time. For most of the early modern era, scholars have therefore been forced, if anything, to infer a strategic rationale from the efforts of the poor towards making a living, while we still lack research enabling the actual strategic decisions and moves behind those actions to be substantiated empirically. It is the aim of the present article to take a step forward in that direction, using English pauper letters as a source which does in fact provide close insights into the strategic choices made by the poor. ${ }^{2}$

The ensuing discussion is based on a particular sample of pauper letters, namely all those surviving among the records of parochial Poor Law administration in the county of Essex (to the northeast of London). This sample of Essex pauper letters comprises 758 pieces dated from 1731 to 1837, all of which will shortly be available in the form of a critical edition prepared by the present writer. ${ }^{3}$ The letters were sent to places in Essex (from where they have come down to us), but less than a third came from places within that county. This is because pauper letters came from people who lived in another parish than that from which they drew their assistance, and seventy per cent of them lived in places outside Essex, mainly in London, the other home counties and East Anglia. Particular emphasis will here be placed on the 270 letters sent from Essex paupers residing in London (coming from twenty-eight per cent of all senders), which survive mainly from 1800 on. Pieces from other places will only be quoted for supplementary purposes. Before we turn to this source, however, it is necessary to give a brief outline of the institutional context from which they derive.

\section{INSTITUTIONAL CONTEXT: THE ENGLISH POOR LAW BEFORE 1834}

The English proletariat of the eighteenth and early nineteenth centuries shared in the social and economic deprivations associated with the early

2. Previous advances include Louise A. Tilly, "Individual Lives and Family Strategies in the French Proletariat", Journal of Family History, 4 (1979), pp. 137-152; Catharina Lis and Hugo Soly, "Total Institutions' and the Survival Strategies of the Labouring Poor in Antwerp, 1770-1860", in Peter Mandler (ed.), The Uses of Charity: The Poor on Relief in the Nineteenth-Century Metropolis (Philadelphia, PA, 1990), pp. 38-67; Lynn Hollen Lees, "The Survival of the Unfit: Welfare Policies and Family Maintenance in Nineteenth-Century London", in ibid., pp. 68-91; Stuart Woolf (ed.), Domestic Strategies: Work and Family in France and Italy I600-1800 (Cambridge, 1991); Catharina Lis and Hugo Soly, Disordered Lives: Eighteenth-Century Families and Their Unruly Relatives (Cambridge, 1996); Tim Hitchcock et al. (eds), Chronicling Poverty: The Voices and Strategies of the English Poor, 1640-1840 (London, 1997); Lynn Hollen Lees, The Solidarities of Strangers: The English Poor Laws and the People, 1700-1948 (Cambridge, 1998), chs 5 and 6.

3. Thomas Sokoll (ed.), Essex Pauper Letters, $x 737-1837$, Records of Social and Economic History, new series (Oxford, in press). 
stages of industrialization throughout Europe. Typically enough, contemporaries took it for granted that manual labour and poverty went hand in hand, and hence referred to the working classes as the "labouring poor". At the height of the debate on pauperism which led to the New Poor Law, the Poor Law Report of 1834 declared poverty as the "natural" condition of the labourer. ${ }^{4}$ In fact, in assessing more fully than hitherto the impact of factors like unemployment or the declining income shares derived from women's and children's work, recent research into the standard of living during the Industrial Revolution in England has again come to rather pessimistic conclusions. Scholars are now agreed that living standards stagnated between 1750 and 1820 , while debate continues as to whether there was much improvement between 1820 and 1850.5

In their entitlement to and benefits from public welfare provision, however, English labouring people seem to have fared better than their counterparts elsewhere, at any rate before the drastic cutbacks under the New Poor Law after I834. ${ }^{6}$ Under the Old Poor Law, all parishes in England (or townships in the northern counties) were statutorily required to relieve their poor. In practical terms, this led to considerable income transfers. In I8021803, for example, total poor relief expenditure in England and Wales amounted to $\mathfrak{f}_{4 . I}$.I million (roughly, two per cent of the national income), with just over one million people or eleven per cent of the population relieved. This was equivalent to $\mathfrak{E}_{3.92}$ per recipient (or $\mathfrak{E}_{0.45}$ per head of the population), a figure whose weight is readily appreciated from the estimated national income per head of $£_{23}$ for the same time. The overall distributional capacity of the system must not, however, make us overlook the small compass of its actual operation in administrative and financial terms. Practically, it was a "welfare state in miniature" (Blaug), consisting of more than 15,000 parochial units, three-quarters of which had a population of

4. S.G. and E.O.A. Checkland (eds), The Poor Law Report of 1834 (Harmondsworth, 1974), p. 334. The best survey of the contemporary literature remains J.R. Poynter, Society and Pauperism: English Ideas on Poor Relief, $1795-1834$ (London, 1969).

5. Maxine Berg and Pat Hudson, "Rehabilitating the Industrial Revolution", Economic History Review, 45 (1992), pp. 24-50; Sara Horrel and Jane Humphreys, "Old Questions, New Data, and Alternative Perspectives: Families' Living Standards in the Industrial Revolution”, Journal of Economic History, 52 (1992), pp. 849-880; idem et idem, "Women's Labour Force Participation and the Transition to the Male-Breadwinner Family, 1750-1865”, Economic History Review, 48 (1995), pp. 89-II7; Charles Feinstein, "Pessimism Perpetuated: Real Wages and the Standard of Living in Britain during and after the Industrial Revolution", Journal of Economic History, 58 (1998), pp. 625-658. For a nuanced summary, see M.J. Daunton, Progress and Poverty: An Economic and Social History of Britain 1700-1850 (Oxford, 1995), pp. 420-446; and for a perceptive statement of the optimistic case, Peter H. Lindert, "Unequal Living Standards", in Roderick Floud and Donald McCloskey (eds), The Economic History of Britain since 1700, 2nd edn, 3 vols (Cambridge, 1994), vol. I, pp. 357-386.

6. Peter M. Solar, "Poor Relief and English Economic Development before the Industrial Revolution", Economic History Review, 48 (1995) p. 122; Lindert, "Unequal living standards", pp. 382383. 
less than 800 people. ${ }^{7}$ From a comparative European perspective, it is also important to note that the system did not involve a great deal of bureaucracy and did not rest on professional personnel. Rather, the overseers of the poor were unpaid parish officers, typically elected from among the leading farmers or shopkeepers within the local community, and often personally known to the applicants. In many cases it was the same group of a dozen. people or so who served the (half-yearly) office in turn over several years. It was only from the I820s onwards that larger parishes increasingly came to appoint salaried assistant overseers. But these still worked along with the honorary officers, and what is more, to the extent that the salaried overseers and vestry clerks stayed in office for years, their personal acquaintance with the poor must if anything have become even more pronounced. ${ }^{8}$

The principle that each parish was responsible for the relief of its own poor, but only for these and nobody else, had enormous practical consequences for people moving between parishes. People who had left "their" parish were still legally settled in that place. Therefore, in case they became poor and applied for relief in another parish, they had to go back (strictly speaking, they were to be removed from the host parish) to their place of settlement in order to be relieved there. Since the late seventeenth century there was the alternative opportunity of obtaining a (new) settlement in another parish, most notably by renting property above the yearly value of Ero, by working as a servant for one year, or by serving an apprenticeship of seven years. But the settlement was thereby transferred to that parish, so that again people could not claim poor relief anywhere else.

For ordinary labourers and their children, apprenticeship and service were the most important ways of "earning" a settlement, the more so since in trying to place their children with masters or mistresses in another parish, labouring families were often supported by the overseers of their own parish. It was a common form of assistance, for example, that the overseers paid part of the premium for an apprenticeship indenture or that they provided a set of decent clothes for a child going into service. In fact, this was also often done when pauper children were placed with masters or mistresses within their own parish. But there was a particular incentive for overseers to arrange for children to be placed in another parish where they would

7. Mark Blaug, "The Poor Law Report Re-examined", Journal of Economic History, 24 (1964), pp. 229-245; idem, "The Myth of the Old Poor Law and the Making of the New", Journal of Economic History, 23 (1963), pp. 151-184; Karel Williams, From Pauperism to Poverty (London, 1981), Tables 4.I and 4.2, Pp. 148-150; W.A. Cole, "Factors in Demand 1700-80", in Roderick Floud and Donald McCloskey (eds), The Economic History of Britain since 1700, Ist edn, 2 vols (Cambridge, 198I), vol. I, p. 64; Lindert, "Unequal living standards", pp. 382-383.

8. Thomas Sokoll, Household and Family Among the Poor: The Case of Two Essex Communities in the Late Eighteenth and Early Nineteenth Centuries (Bochum, 1993), pp. 124-130, 221-235; David Eastwood, Governing Rural England: Tradition and Transformation in Local Government 1780-1840 (Oxford, 1994), pp. 99-165. 
earn a new settlement, since they could thereby "export" future claimants. By the early nineteenth century, however, these opportunities were largely exhausted, as employers had come to prefer "pure" wage labour to living-in apprentices and servants. ${ }^{9}$

The traditional view that the English Poor Law, by tying people to their parish of settlement, acted as a disincentive to migration has proved untenable. ${ }^{10}$ Early modern English society was, and remained, an inherently mobile society, even though long-distance migration may have declined during the eighteenth century. ${ }^{\text {II }}$ It is, nevertheless, obvious that the administration of the settlement laws did influence migratory behaviour, though the precise mechanisms are complex and difficult to discern. In fact, there has been a major reconsideration of this issue in recent research, with some scholars stressing the selective use of the law by parish officers and suggesting that it served as an effective instrument for the regulation and "monitoring" of people's migration. Others have been less prepared to accept this view and cast doubt on the notion of a close "surveillance" of the movements of the labouring poor by local vestries. ${ }^{\mathrm{I2}}$ But most would probably agree that one of the chief effects of the settlement laws was "to deter the migrant poor from claiming relief - for fear that they might then be moved out". ${ }^{13}$

However, precisely that deterrent effect was not necessarily all that powerful, given that there was still an alternative to the removal of the claiming

9. James Stephen Taylor, "The Impact of Pauper Settlement 169I-1834", Past and Present, 74 (1976), pp. 42-74; Paul Slack, The English Poor Law, I531-1782, 2nd edn (Cambridge, 1995), pp. 27-3i. For the erosion of service and apprenticeship since the late eighteenth century, see K.D.M. Snell, Annals of the Labouring Poor: Social Change and Agrarian England, 1660-1900 (Cambridge, 1985), pp. 67-103, 228-269.

10. The traditional view goes back to contemporary authorities such as Adam Smith and was canonized by Sidney and Beatrice Webb in their classic study of the Poor Law: English Poor Law History. Part I: The Old Poor Law (London, 1927), pp. 314-349.

II. Peter Clark and David Souden (eds), Migration and Society in Early-Modern England (London, 1987); Ann Kussmaul, "The Ambiguous Mobility of Farm Servants", Economic History Review, 29 (1981), pp. 222-235; Arthur Redford, Labour Migration in England, 1800-1850 (London, 1926; repr. Manchester, 1964).

12. Norma Landau, "The Laws of Settlement and Surveillance of Immigration in EighteenthCentury Kent", Continuity and Change, 3 (1988), pp. 391-420; idem, "The Regulation of Immigration, Economic Structures and Definitions of the Poor in Eighteenth-Century England", Historical Journal, 23 (1990), pp. 54I-572; K.D.M. Snell, "Pauper Settlement and the Right to Poor Relief in England and Wales", Continuity and Change, 6 (1991), pp. 375-4I5; Norma Landau, "The Eighteenth-Century Context of the Laws of Settlement", Continuity and Change, 6 (1991), pp. 417-439; K.D.M. Snell, "Settlement, Poor Law and the Rural Historian: New Approaches and Opportunities", Rural History, 3 (1992), pp. 145-172; Roger Wells, "Migration, the Law, and Parochial Policy in Eighteenth and Early Nineteenth-Century Southern England", Southern History, Is (1993), pp. 86-139; Byung Khun Song, "Agrarian Policies on Pauper Settlement and Migration, Oxfordshire 1750-1834", Continuity and Change, I3 (1998), Pp. 363-389; idem, "Landed Interest, Local Government, and the Labour Market in England, 1750-1850", Economic History Review, SI (1998), Pp. 465-488.

13. Slack, English Poor Law, p. 30. 
migrant, which was in fact of immense practical importance. This was the administration of nonresident (or outparish) relief, which meant that people who resided in another parish than that of their settlement were simply not removed but supported at that place, on the basis of informal arrangements between the two parishes concerned. There were basically two forms. Either the overseers of the "host" parish advanced the necessary payments, possibly at their discretion, and had them reimbursed by the "home" parish; or the home parish made the payments straight away, whether directly to the recipient or through the hands of others.

It is at this point we may now return to our major theme, for it is mainly people in receipt of such nonresident poor relief to whom we owe pauper letters. Precisely why those witnessed in our sample of Essex pauper letters had originally left their home parish is often not known. But it seems reasonable to assume that the main reason for migration was the search for better employment opportunities. With respect to people who had gone to London, it may also be assumed that on the whole their prospects in the metropolis were actually better, even for those who had run into trouble and turned to their home parish for relief. Under these conditions, the agreement on nonresident relief had clear advantages over removal for both parishes. Removal involved considerable expenses, which (after 1795) fell on the removing parish. For a labouring couple with children, these could easily amount to IIO $_{\mathrm{O}}$ or more. ${ }^{\mathrm{I4}}$ Once removed, the homecomers were to be relieved in their parish of settlement, where they had fewer opportunities to make a living - after all, this is why they had left for London in the first place. In such cases it was simply cheaper for the home parish to provide nonresident relief, that is, to leave people where they had gone to live and arrange for their allowance to be sent there.

The suggestion that, under certain conditions, parishes may thus have benefited from the administration of nonresident relief is also supported by the fact that this practice of poor relief was fairly widespread. Official Poor Law statistics are notoriously defective in this respect (which is probably one reason for the long neglect of the entire issue of nonresident relief in previous research), but an overall average figure of fifteen per cent of all paupers being nonparishioners in England in 1802 is probably a good guess. The county average for Essex was about the same. By that time, Essex had lost its former cloth industry, centred in places like Colchester, Braintree and Coggeshall, and had turned into an agricultural county with high levels of seasonal unemployment and above-average poverty. Places like the ones just named had an estimated twenty to twenty-five per cent of their paupers residing elsewhere. ${ }^{\text {Is }}$ It is to people from that group of paupers or, more precisely, to those among them who addressed their overseers in writing, that we now turn.

14. Snell, Annals of the Labouring Poor, p. 18.

15. See Sokoll, Essex Pauper Letters, "Introduction", ch. 2. 


\section{PAUPER LETTERS: AN EXEMPLARY CASE AND A BRIEF OUTLINE OF SOURCE CRITICISM}

Pauper letters are of major importance for the social history of poverty from below, since they provide - literally - first-hand evidence of the experiences and attitudes of the poor themselves. Despite this, however, English pauper letters are as yet virtually unknown to social historians, and research on them is still in its infancy. ${ }^{16}$ They are also exceptionally delicate pieces of literary evidence. This poses immense problems for their historical analysis and interpretation, especially when, as in the present case, the evidence is cut into small pieces along thematic lines. Therefore, in order to introduce this unique type of record to the reader, it is appropriate to begin the discussion by presenting one letter in full.

London october 251827

Genteelmin I am obliged through Real distress to apply for Releaf as you Will See I dont decerve you my fits have been Such as to dissable me from Workin to keep my Family the ro shillings you Was So kind as to leave me I Put it to the Best use I Could you are Well aware how far Such a Sum of money Will Goe I Was ordrd By this Parish to Send to you the Gentleelmin Was So kind as to Give me 2 Shillings [= Iop] I have 7 in family With my Wife Self and No house to Be in I am distresst Beyound and all I Ever met With and hope the Genteelmin Will take this in to Consideration and Releave me if Not I am Come to So much disstress I must Come Home With my Family if I Was Settled and had my few things I Would try and do all I Could Not to trouble you as I am much better in Helth if I had applid to you for my Rent this might have Been Prevented But I Was in hops I Could have done With out troublin you an answer to this Will be thankfulley Recevd by David Rivernell

${ }_{4}$ Grove $S^{\mathrm{u}}$

Direct to $\mathrm{M}^{\mathrm{r}}$ Howe

Commercial Road

This letter was sent from David Rivenall in London to the overseers of the poor of Chelmsford (23I). ${ }^{17}$ With respect to its formal characteristics, the

16. James Stephen Taylor, Poverty, Migration and Settlement in the Industrial Revolution: Sojourners' Narratives (Palo Alto, CA, 1989) is based on pauper letters from Cornwall, Devon and Westmoreland. The extraordinary sample from Westmoreland is also used in idem, "Voices in the Crowd: The Kirkby Lonsdale Township Letters, 1809-36", in Hitchcock et al., Chronicling Poverty, pp. 109-126. For the first fruits of research on Essex pauper letters, see Thomas Sokoll, "Selbstverständliche Armut. Englische Armenbriefe, 1750-1850", in Winfried Schulze (ed.), Ego-Dokumente. Annäherungen an den Menschen in der Geschichte (Berlin, 1995), pp. 227-270; Pamela Sharpe, "The Bowels of Compation': A Labouring Family and the Law, c. 1790-1834", in Hitchcock et al, Chronicling Poverty, pp. 87-108; Thomas Sokoll, "Old Age in Poverty: The Record of Essex Pauper Letters, 1780-1834", in ibid., pp. 127-I54.

17. For the sake of simplicity, all references to the Essex pauper letters are given in parentheses within the main text, by quoting the number of the piece within the edition (Sokoll, Essex Pauper Letters). The same holds for other parish records referred to, where the details will be found in 
modern reader might find the slightly phonetic spelling, the idiosyncratic capitalization, and the complete lack of punctuation a little irritating. Otherwise, however, the piece is not much different from a letter as we know it today. There is a clear, if simple, layout, and the standard epistolary elements are all given (place of sender, date, salutation of the recipient, main text, valediction, address of sender). Admittedly, the substantive message is slightly obscured by the fact that the wording and style are a little clumsy and that the narrative is somewhat poorly structured. Nevertheless, apart from a few apologetic phrases, the main points themselves are given in plain prose and leave no doubt about the sender's situation and the purpose of his writing. Illness has prevented him from work; he obtained relief from the overseers of Chelmsford (which he gratefully acknowledges) but it has proved insufficient; his goods have been (or are about to be) distrained because of his arrears in rent. He applies for further relief, apparently to enable him to redeem (or keep) his goods, and points out that if this is not granted he and his family will have to go "home" to the parish of Chelmsford.

David Rivenall lived in London, in the parish of St George in the East. But he received poor relief from Chelmsford, the administrative capital of the county of Essex (some thirty miles from London), since that was the place of his legal settlement. He was never removed to Chelmsford but stayed in London. The parish of St George in the East never even threatened to send him "home", while the overseers of Chelmsford on their part did not want him to come "back" and were actually quite happy to assist him in London as long as he stayed there. This is why he could threaten his parish to "come home" with his family in order to put more emphasis on his request for relief.

David Rivenall and his family are in evidence from Christmas 1819 till May 1829, mainly through the thirty-four letters surviving from him and his wife, but also through several other overseers' records from Chelmsford. Throughout that period, he received poor relief from there, in the form of a regular weekly allowance ranging between 4 shillings and 6 shillings (2op and 3op), with additional payments on particular occasions. ${ }^{18}$ The money was handed out to him by people authorized from Chelmsford. There was a certain Mrs Nelson in Whitechapel, and later on Mr French, a coachman travelling between Chelmsford and London. Through these people, and through correspondence with the overseers of the parish of St George in

the critical apparatus of the edition, under the respective letter. All records are kept at the Essex Record Office (ERO) in Chelmsford and the ERO branches at Colchester and Southend-on-Sea. The precise archival references of all sources quoted in the present article are also given in the edition.

I8. For readers unfamiliar with the traditional monetary units $(\ell I=20$ shillings $(s)=240$ pence $(d)$ ), modern decimal equivalents $\left(\mathcal{E}_{I}=\right.$ roo pence $\left.(\mathrm{p})\right)$ have been added in brackets after quotations of specific amounts of money. 
the East, the overseers of Chelmsford were kept up-to-date about Rivenall's situation. Moreover, in December 1823 , at about the same time from when his first letter survives, John Sheppee, a representative of the select vestry of Chelmsford, had been sent to London to call on all Chelmsford paupers residing in the metropolis. He reported that David Rivenall was then fortytwo years old. His wife Sarah was forty, and they had seven children aged between twelve years and five months. Rivenall had just had the household goods distrained for arrears in rent of ro shillings (= 5op) "in consequence of not receiving his allowance as he formerly did". Sheppee went on:

I gave him $\mathrm{Er}$, and told him all the allowances were stopt for the present, and that he must not expect so much as $5 s /$ [ 2sp] per Week for the future; - The Family look in a very deplorable state; - it appears the Children are shut up in the house all day, as the Wife keeps a Stall and the Husband acts as a Porter in the day time and carries Oysters about in the Evening; - They appear to me to be both fond of Dram drinking [...] (104).

One might perhaps expect that Sheppee's final remark cast doubts among the overseers of Chelmsford as to whether the Rivenalls were truly deserving objects of charity. But this does not seem to have been the case. Occasionally, the relief payments were delayed, but this was a normal complication in the administration of relief to nonresident paupers.

It is impossible here to go through the record of the thirty-four Rivenall letters in detail. But is worth listing some "highlights" of their case, following their letters in chronological order. In May 1824, David wrote from the Clerkenwell House of Correction, where he was imprisoned for debts of $£_{2}$ (116). In August of that year, one child died (130). In November 1825, the attempt failed to place the eldest son David as an apprentice with a "very respectable" master in the City (175). In April and May 1826, two further children died, Alfred and Edward (190-192). The funeral costs amounted to $£_{2} 9 \mathrm{~s}\left(=£_{2.45}\right)$, and Chelmsford sent an extra allowance of $£_{I}$ (one letter [192] was written on the same sheet as the undertaker's bill). In August 1827 David Rivenall was in the debtors' prison at Cold Bath Fields. The letter he sent from there is also the first one mentioning that he was suffering from fits. It is worth quoting more fully.

I have been labouring under the greatest distress for some time past being quite out of Employmt, but did not wish if possible to trouble my Parish as I was in hopes that when the oyster season would comme[n]ce that I should be able to get round and provide for my poor family by selling of oysters in which I have been always Tolerably Lucky but Just as the season began I was taken and put in prison for a the small sum of twelve shillings and Six pence $[=62.5 \mathrm{p}]$ which I had no mains on earth of paying so that I now remain in Confindment and Know not what will will become of my poor wife and Childrens I have also the unhappiness to State that I have been very lead in my health for a long time and are severely troubled with fits I have had several since I came to this Prison and in the Prison 
chapple on sunday I had a severe one and was obliged to be taken out in the middle of the service. (225)

The next letter, of 25 October 1827 , is the one printed in full at the beginning of this section (231). That letter, as we have seen, is somewhat unclear with respect to the distraint of his goods by his landlord for arrears in rent. As a matter of fact, the goods were distrained two days later (232). Thereafter, David's fits occurred more and more frequently, while Sarah had growing trouble with her stall in the street (239). In June 1828, David was admitted to the London Hospital where he spent two weeks (249-250). Meanwhile, at least two of the boys had been placed in service (239), and there were prospects of finding places for the two girls as well (257). In May 1829, Sarah gave birth to male twins and David said he needed a nurse for her (275). The last Rivenall letter came from Sarah. Apparently the two girls had not been able to go into service because they had no decent clothes. Otherwise, the family suffered from "the continued Severe illness with which my Husband has been afflicted for the last 3 months, \& which has reduced us to the lowest ebb of poverty"(277).

The thirty-four letters from David and Sarah Rivenall date from December 1823 to May 1829. Most of them are in his name, but three letters came from her, and six were signed in the names of both. Whether they physically wrote any of them themselves is not known. The thirty-four letters are in sixteen different hands. Their next-door neighbour, Michael Howe, wrote six of their letters, including the one quoted in full (231), as is evident from a letter in the same hand in which he addressed the overseers of Chelmsford in his own name: "Jenteelmin knowin david Rivernalls distress, I advanced him the money to Releave his things and Shall be Glad if you Would have the Goodness to Convay it to me" (232). With thirty-four pauper letters and further evidence, including correspondence from other people, the case of David and Sarah Rivenall is exceptionally well documented. Otherwise, however, there is nothing special about it. The issues brought up are also witnessed in other pauper letters. In substantive terms, the Rivenall letters may therefore be regarded as a fair representation of the sample of Essex pauper letters on the whole. But perhaps the most important point to note here is the particularly clear evidence of the strong negotiating position in which the Rivenalls found themselves. They knew why they were not removed. And so, it seems, did most other pauper letter writers. In fact, their knowledge of the disadvantages of their removal to their home parish was the poor's best card, and it is precisely their letters which reveal how effectively they played this card.

This brings us to the question of source criticism, though again it will be understood that only a few remarks can be made here. ${ }^{19}$ From our foregoing

19. For an extensive discussion of the questions involved in the source criticism of pauper letters, with particular emphasis on their importance for the social history of literacy, see the Introduction to Sokoll, Essex Pauper Letters. 
discussion, it follows that pauper letters are essentially strategic pieces of writing. It would, nevertheless, be wrong to read them only with respect to the strategic interests they express. Rather, in what the letter writers felt they had to say about their condition, they often go far beyond mere strategic considerations, and open deep insights into the everyday life of the labouring poor. Moreover, in linguistic terms, pauper letters "sit" closer to the experiences and attitudes of the labouring poor than most other records. Some of them, especially those written with heavy phonetic spelling, may almost be regarded as "oral" testimonies. The fact that pauper letters were not necessarily all self-written does not invalidate this. The important point here is rather that, among the hundreds of different hands in evidence in the record, there are hardly any hands of professional scribes. Thus, when the poor arranged their letters to be written by other people, they seem to have turned primarily to members of the family and to relatives, friends and neighbours. In other words, whoever actually wrote these pieces, we can be reasonably certain that, apart from a few exceptions, pauper letters all come from within the sociocultural milieu of the labouring poor.

But would it not be naive simply to assume that pauper letters give "true" representations of their senders' circumstances? And is it legitimate to regard them as a mirror of the experiences and attitudes of the labouring poor in general? Although it is impossible to check the details of the account of the sender's case against external evidence for every individual letter, there is good reason to believe that, on the whole, pauper letters possess a high credibility. This is not to deny that there is an inbuilt "make-up" of the stories which are typically told. For example, in what people chose to say (and what not to say) they were to a certain extent guided by what they thought the overseers would want to hear. We should also expect a certain amount of exaggeration. It is even possible that individual letter writers gave false evidence and tried to deceive. But this last option must have been absolutely exceptional, given that nonresident paupers were subject to social control from two sides, with both home and host parish being alert to them. As we have seen, David Rivenall was visited at his place in London by a representative of the select vestry of Chelmsford. His money was brought by people in close contact with the overseers of his home parish. In his letter of 25 October 1827 , he mentions that he also approached the overseers of St George in the East, his host parish (and that they advised him to write and send that letter). There was correspondence about his case between the overseers of the two parishes. None of this was exceptional. In fact, for many Essex pauper letter writers, the record of correspondence between the parishes concerned is particularly rich. Thus, if anything the surveillance of nonresident paupers must have been closer than that of those residing in their parishes. Otherwise, however, there is no evidence of any major differences between the two groups, which means that there is no reason why 
the views expressed in pauper letters should differ from those held by the labouring poor at large, or at least by those receiving relief.

\section{LABOUR AND THE TIDES OF TRADE}

David and Susan Rivenall made a living, or rather tried to do so, from hawking, selling fish and oysters and whatever casual work they were able to pick up. Most Essex paupers writing from London seem to have been dependent on casual labour. This is not surprising. The metropolis was notorious for its vast casual labour market, especially in the East End. ${ }^{20}$ The majority of the letter writers, as indeed the Rivenalls themselves, use rather unspecific terms to describe their efforts, saying they live from "selling things" (56, 6I, 285). Occasionally, more details are given. Thus, John Spearman wrote that he had "Bought Some things for the first time and whent all the way [from London] to Arcot [mistaken for Ascot] Races A Distance of thirty miles to Sell them from which place I arrived last Night just Sixpence out of pocket by the journey" (64). James Howell, who was based in Ely, pointed to the importance of credit involved in his undertaking: "I have six Children and the way I Get them bread is Carring a fue things to sell about the Country I have Lived in the town a long wile and by been nowen I have the Goods in Creadett". He was particularly concerned about obtaining a new licence and reminded the overseer of Braintree that the parish had always met half of the yearly fee: "Gentlman if you look in the book you will find that two pounds is what I have per year towards the four that is what I hav to pay for the Licences" (456). Two years later, he wrote that he was hardly able to get on: ${ }^{\alpha} i$ have nothing to trust to for trade but hawk the Cuntry afew Goods as $\mathrm{i}$ have in Credite and so $\mathrm{i}$ have been on for sixteen years but Gentlman at this time $i$ ham drove at my witsens [wits' ends]" (487).

Some people tried to specialize in particular products. Elizabeth Goodman, in the London parish of Shoreditch, reported about her daughter Marian, stressing the latter's "great anxiety for her Fatherless Children, \& perseverance to maintain them, her fatigue is great some days she walks from I5-to 20 Miles to deliver her Tea, $\&$ at her return is quite exhausted who could have thought she would have been able to get through what she has" (663). Samuel Hearsum, in the parish of St Marylebone, also sold tea, which brought him 6 shillings per week (no). Issac Harridge in Newington sold quack medicines and booklets (II8). John Tye in Colchester sold books and asked the overseers of St Botolph's parish to supply him with "wrighting paper and a Couple of Hundred of Quills that I Could Cut into pens at

20. Gareth Stedman Jones, Outcast London: A Study in the Relationship between Classes in Victorian Society (Oxford, 1971), pt. I; E.J. Hobsbawm, "The Nineteenth Century London Labour Market", in Ruth Glass et al., London: Aspects of Change (London, 1964), pp. 3-28, 12-13. 
My Leasure - with a few Sweets of my own makeing To make up a Load and to take a regular Curent round Colchester". It looks as though he not only sold books but also read them and knew how to use a pen, for he began his letter rather effectively: "It is with a Trembling hand I beg to Intrude this Letter" (364).

There are also references to tinkering and mending. Isaac Wright, in the parish of St Alfege in the City of London, said he was "fitting Tea Kettle Handles, \&c which amounts to 3 or 4 shillings [I5p or 20p] weekly" (256). William King in Bethnal Green, who seems to have been a shoemaker by training, was hoping to make a living from mending shoes:

My Shoes are Nearly of My feet. I have Mended them till they are Got No foundation to work Upon - I Get a Little work ore we Should Starve But I Know Not How Long that will Last Yet as the Summer is Comeing I feel of Hope that if I was Set a Little for ward I Might Mend ore Make a few Slop womans Shoes and So hold out the Season. (38)

From his later letters, however, one gets the impression that he did not succeed in this. The only other known shoemaker in the sample, John Thurtell, does seem to have been able to work in his trade. He lived in Romford and received his leather from Mundon, the parish where he was settled (626).

Some people were in specific trades. James Albra, in the parish of St Andrew Holborn, was a bookbinder. When he fell ill early in 1829, his wife wrote to Chelmsford that he had "bin ill 3 mounth not bin able to harn a fathen" (270). George Tye, in the parish of St Anne Soho, had previously made it to Brussels where he "was Employd as a man Cook and Confectioner to verious English Famelys passing and repassing through that City till my Return to This Countrey [...] Since which time I have lived as a wanderer by my Industrey warever I Could git Employd to the presant peirod" (334). William Willsher in Norwich had been a baker, but "through acomplaint I am afflicted with I cannot follow the Bakers trade nor has not for these 8 year's for I have been Weaveing but no worke of that kind is going in Norwich at this time Numbers agoing to their towns every day for want of work" (515). Norwich had long lost its former role as a centre of the woollen cloth industry. It is no wonder, therefore, that the other references to weaving, most of which also relate to that place, mainly speak about the lack of employment (285). Silk weaving in Bethnal Green was also reported to be slack (287).

Most people, however, do not name any particular occupation or trade. In fact, the usual expression is to say no more than that people "work" or "do" all they can for themselves and their families - but still are unable to obtain the "common necessaries". Given that pauper letters are strategic pieces of writing, it might perhaps be argued that tales of the daily toil involved in earning your bread were an almost compulsory thetoric exercise. 
After all, in a society which held that it was only natural that for the majority of its members labour and poverty should go hand in hand, and whose middle class was about to accentuate its work ethic ever more mercilessly under the ideological device of "self-help", people applying for poor relief would indeed have been ill advised not to point out their willingness to work and to do all they could towards gaining a living. ${ }^{21}$ But then it is all the more surprising how little the record of pauper letters provides in this respect. For it is not so much the few passages explicitly concerned with work which are most striking: it is, rather, the general lack of detail in this respect and the overall silence about the precise nature of people's work.

There seem to be two reasons for this. The first is the semantic problem of how to talk about work without the notion of a clearly defined occupation or trade. A shoemaker might dwell on the various kinds of leather he uses, the types of shoes he makes, or the changing fashions of his customers. A hewer might refer to the heat at the coal face, or take pride in the strength of his body. But how is a casual labourer supposed to express his experience of work? The linguistic record of the pauper letters is instructive in this respect. The substantives "work", "trade", "business" and "employ" are used more or less interchangeably, and it is typical to say that work or trade is "bad" $(347,369)$, "slack" $(26,445)$, "dull" (20I), "falling off" ( 175$)$, "fallen short" $(298,309)$ or "dead" (445). Thus, the terms used in this semantic field are rather unspecific, if not to say vague. At the same time, they are mainly used from an individual perspective. People normally talk just about their own personal struggle against the vicissitudes of trade. Only very occasionally is the personal experience put into a wider context, as in the following statement by George Craddock from Westminster:

[...] my health is very bad that I am not able to do any laborous work at all the only thing I have done Since I returned from the Country is to Sell alittle fruit or go Sometimes on an erant or any light Employment I can Get to do and there is at this time so many thousands of Strong hearty men out of work in london that it is Almost Imposable to get any thing to do at all. (\$22)

The second reason for the relative silence in pauper letters about work is a more general one: namely, the fact that people tend not to talk about the self-evident, the obvious, and the normal, not least because they might also think that this is not what the overseer wants to hear. For example, there

21. It is striking how "indigence" was distinguished from "poverty" in the Poor Law Report of 1834 (following Colquhoun). Indigent and hence worthy of assistance were those who were "unable to labour" or "unable to obtain, in return for his labour, the means of subsistence", whereas the "pauper" had no claim, given that poverty was the natural "state of one who, in order to obtain a mere subsistence, is forced to have recourse to labour" (Poor Law Report, p. 334); see Patrick Colquhoun, A Treatise on Indigence (London, 1806), p. 8. 
is hardly ever anything said about the "family economy", because it is simply taken for granted that all members of the family work, according to their capacity, and contribute to the common income. This is also the reason why there are only very few references to the work of women or of children. It is only when the normal cause of things is disrupted that people begin to tell, and it is from these accounts of the exceptional that we can infer the rule. ${ }^{22}$

Perhaps the most common experience of such exceptional conditions in the field of work is the loss of bodily strength in elderly males. It is again George Craddock in Westminster who expressed this succinctly when he declared to the overseers: "would to God I was able to Labour hard as I formely have done and that it was as easily procured as then - then I should not have Trobled them for assistance but those good days are gone for ever from me" (530). Another example, in fact perhaps the most moving statement in this respect, is that made by William James in Chelmsford:

[...] for many weeks past, sometimes work, \& sometimes none, my Earnings have been but small, not more on Avarage, than six Shillings, or six, and six pence, a week, as near as I can tell - (I may say for some Months this have been my case) with which we cannot procure Necessaries, to support health nor Nature, for the want of which, I find health and strength decaying fast, so that when I have a little work to do, I find myself, through Age, and fatigue, incapable to perform it, Walking into the Country five or six Miles in a morning, working the Day, and returning home at Night, is a task that I cannot, but without great dificulty perform, several times I have thought, I could not gett home, and it have been the Occasion, of my being Ill, for two or three days, this I attribute, in a great degree, to the want, of constant Nourishment, to keep up my strength, and of Age aded there too, being now within one Year of Seventy - at this time I am Unwell, and have been several days $(454) .^{23}$

\section{HOUSEHOLDING}

Most Essex pauper letter writers must have been simple day labourers. Those writing from places in East Anglia were probably mainly landless agricultural labourers, as indicated by references to work in the fields and stables (4) or at haytime and harvest (56). Most of those residing in London, as we have

22. The silence about basic features of family life even in autobiographies (and, for the more recent past, in oral history interviews) is a well-known problem to historians. See David Vincent, "Love and Death and the Nineteenth-Century Working Class", Social History, s (1980), pp. 226232; idem, Bread, Knowledge and Freedom: A Study of Nineteenth-Century Working Class Autobiography (London, 1981), pp. 40-46, and, with special reference to the family economy, pp. 62-86. For the difficulties of distilling contemporary notions of the family from literary works, see Naomi Tadmor, "The Concept of the Household-Family in Eighteenth-Century England", Past and Present, ISI (1996), pp. III-I40.

23. For a more detailed account of the case of William James, see Sokoll, "Old Age in Poverty", pp. 144-145. 
seen, seem to have been casual workers picking up whatever "jobs" they could obtain, with some of the women doing needlework (162, 663), washing $(289,338)$, and mangling ( 133$)$ for other people. This means that for the overall majority of the people we are concerned with here, the household was definitely not a place of production. The very few references to weaving (most of them in the negative) or other trades involving work at home are merely exceptions to prove this rule. So are the few cases where home production of clothes is referred to, as in the outcry from Mary Taylor in Hadleigh (Suffolk): "you promised me Sir to send me a peice of cloth to make my Children some shirts [...] but yet Sir you did not perform your promise" (322).

The usage of the very term "household" is instructive. Not only is it very rarely used at all, but when it turns up it refers only to reproductive or "housekeeping" functions. "Our Household is But Very Mean, My Wife is But a Poor afflicted woman", says William King in Bethnal Green (32). This is the notion of the household as a consumptive unit, based on the nuclear family of a married couple with children, where the wife is responsible for the "management" of the household. But this is not normally said explicitly, or at least not in these terms. The wife may be said to "do" for the family, but again this is not normally said explicitly because it is simply taken for granted. It is only when the normal household arrangements are disrupted that people talk about them. Thus, when the wife is ill or otherwise incapacitated, the husband might take her place, as George Rowe in Bocking did, "for the State that my Wife is in of Blindness I am forst to have me to Do for Uss" (463). More often, of course, the mother's role is given to the eldest daughter, as in the case of Samuel White in Halstead, reporting that "my eldest Daughter who is now fit for service is (much against her inclination) obliged to keep at home on account of my wives inability to Do for the Family as our Child more than a year $\&$ half old is still unable to stand alone" (252). His eldest daughter was then fourteen years old, but had already managed the household for about two years, as we know from an earlier letter (207).

In particularly critical cases the household needed extra help from outside, which had to be paid for. The case of David and Sarah Rivenall may again be quoted here. In February 1829, Sarah wrote that he was "again suffering under [h] is Old Complaint he has several severe fits of late which has left him in so low and melancholy state that requires some one constantly to mind him which prevents me entirely from endeavouring for support for my Children" (265). At that time, she was pregnant. Three months later, it was David who wrote that she had given birth to two boys but was "in a dangerous state" so that he was "Obligd to have A Nurse" (275). Thomas Hall in Bermondsey in London was in a similar situation,

[...] for $i$ have work to do but $i$ am not able to do it for $i$ have bean very ill and my Wife is had a bad Brest and not able to do for her self and famley [...] my 
wife expcets to be Confined evry day and i cant Get a nus [nurse] or for les then 4 shilen a weak (339). ${ }^{24}$

William Ardley in Kelvedon wrote that "my Wife and Child have been bad with the Bad Fever for some weeks [...] I have been Obige to have a Woman to do for my Family" (IOO). Assistance for women during the last weeks of their pregnancy or after delivery, especially when there had been problems, was a common form of poor relief.

Predictably, the death of a parent posed particularly hard problems. Thomas Albion in Cambridge lamented the "Unfortunate situation Which I have been placed In since the Loss of my Wife, being left with Four Small children and no person to take care of them, but by Hiring a Woman, and having to Maintain her has Hadded much to my present difficulties" (89). Needless to say that widows with children were not only far more numerous than widowers, but also a lot worse off. Susan Pitt, a widow in the parish of St Giles in Colchester, "being unable to maintain the expences any longer", went so far as to say that she was "going to break up House keeping [...], by which my Daughter Sarah Baxter a Girl at the Age of is Years will be entirely destitude of any person to look after her conduct”. This announcement to give up the household needs to be seen in the context of her attempt at having her daughter taken care of by the overseers. She urged them to provide her daughter "an ass[y]lum in the poor house of the parish of St Botolph to which parish she belongs ${ }^{\infty}$, not forgetting to mention that the daughter had "constant employ at the Silk factory at the Weekly Wages of $5 \mathrm{~s} /$. per week" $(382)$.

In other cases, however, it seems to be genuine when people express the feeling that extraordinary hardship endangered the very existence of the household. Sarah Rivenall wrote in January 1825:

[...] my Husband Is Weary Bad And Cannot help himself No more then A young Child And Cannot go Across the house if he Could gain [A th]ousand pound Neither Can he Go to bead nor Get up without A man to help him to Bead And From Bread I Cannot shift no for Now my husband is laid Aside All is Laid Aside with me therefore I must Surmit [your] Ge[ntel]m[en] [paper torn] mercy For if you Gentellmen do not please to help us we must Give up housekeeping For out of nothing thear $\mathrm{Ca}[\mathrm{n}$ nothing be (?)][paper torn] Done. (I42)

The question of housekeeping also relates to the material set-up and the physical space of the household. Again, the first thing which needs to be said is that pauper letters do not normally deal with people's dwellings and their furnishings, or with people's resources in terms of elementary material goods. They do, however, allow certain basic material standards to be assessed from the way in which people talk about the lack of goods apparently regarded as absolutely essential, even for the poorest people.

24. The case of the entire Hall family is described in detail by Sharpe, "Bowels of Compation". 
Among the basic necessaries, shoes (and perhaps, by implication, stockings) stand out most clearly. Bare feet, especially bare feet of children in winter, signify a state of absolute deprivation, which was regarded as unbearable and utterly unjustifiable (322). Sufficient clothing for summer and winter were also seen as indispensable. Underwear, however, is only very rarely mentioned. Elizabeth Goodman, who lived in the London parish of Mile End Old Town, was exceptionally explicit when she stressed "how much, very much I am distress'd for under linen, stockings (of which I have but one pair, \& those mended all over) $\&$ indeed wearing apparel of all sorts" (673). By contrast, outdoor clothes and shoes are mentioned more prominently. This is, of course, not simply because they are more important in physical terms for the protection of body, but also, and perhaps most particularly so, because they show a person's condition in the open, in public. Hence the deep feelings of shame expressed in letters reporting the pawning of outdoor clothes. In the letter just quoted, Elizabeth Goodman lamented that "I was oblig'd to put my only decent Gown in pledge to make up the money $\&$ have not had it in my power to redeem it since, $\&$ by that means have not been able to go out of doors to or even to a place of worship". A similar example is that of William King in Bethnal Green. In December 1830, he wrote: "Every Little Debt is Now Looked $U_{p}$ for and I am ashamed to Pass the doors Where I owe the Money"(37). A year later: "I owe Menny a Shilling Round the Places and our few Cloaths a[re] Mostly all out or My wife Might apear More tidey. I Lost My Best Coat a week or two a Go wich was in for $\mathrm{s}^{\mathrm{s}} .6^{\mathrm{d}}[=7.5 \mathrm{p}]^{\mathrm{p}}$ (51). It was normal for people to pawn their clothes to raise small sums of cash to redeem their debts. Another ten months later, King's "best coat" was again (or still?) with the pawnbroker: "we have a few old Cloaths Given to Us Now and then [...] My old Great Coat wich hides the Rufull tokens of want and Poverty will take $2 / 6$ [=12.5p] to Redeem" (54).

Within the physical bounds of the household, individual possession of or access to particular goods seems to have been less important. For example, George Craddock wrote from Westminster that his children had no shoes and that there was only one sheet, one coverlet and two blankets for the whole family. This, he said, was not enough any longer since "our Children are Grown to[o] Big altogether to Sleep in the Same bed with us we want to Make up another Place for them to Sleep in and Cannot do it without Alittle help" (489). Thus, he was obviously thinking of one bed for his wife and himself and another one for the children. But he did not regard individual bedlinen, let alone an individual bed, as necessary for each member of his family.

This is not to say that the poor were of necessity lacking in more precious objects altogether. In fact, recent research on the material possessions of the poor undertaken by Peter King, using pauper inventories from Essex in the eighteenth and early nineteenth centuries, has even found such items as 
looking-glasses, clocks, pictures, and mahogany and walnut furniture in the households of the poor. ${ }^{25}$ To a certain extent, this picture is also confirmed by the evidence to be found in pauper letters. Some of them mention silver spoons, watches and rings $(67,288)$. Typically enough, however, such luxury items are only referred to when people had been forced to pawn them in order to raise cash. This means that the actual physical possession of such goods was often suspended. The "best coat" or the wife's ring were not constantly worn. They also served as small capital. After all, pawning was the most common source of credit among the working classes well into the twentieth century. ${ }^{26}$

While clothes and private luxury items might therefore be given away by the poor themselves, their household goods were normally taken away by others. The most frequent form of this was the seizure by the landlord of the "goods and chattels" of people who had run into arrears in rent. This is no wonder, given the substantial increases in rents during the period under discussion. ${ }^{27}$ In numerous cases, however, people succeeded in preventing the threatened seizure of their household goods by obtaining assistance from the overseers of their home parish. The granting of a lump sum of to shillings (= 5op) or $\mathfrak{E I}_{\mathrm{I}}$ was a common practice in such cases, and of course the accounts of threatening procedures as given in pauper letters need to be seen against that background. On the other hand, the poor did have a good point here, since their situation was indeed likely to get even worse through the loss of their goods. This was particularly true when tools or working utensils were involved, as in the case of John Spearman in London: "I am expecting Some work about a week or A fortnight time but the most of my tools are in pledge and I hope you will be so kind as to let me have A trifle as Soon as possible to redeem them" (7I). But there are also cases where the creditor himself gave in. A particularly vivid account is given by George Watson in Shoreditch who reported that "when the Gent ${ }^{\mathrm{n}} \&$ his two Men Came into my Place and saw me Ill and my Chilldren almost Naked Looking Round at they Things says he Those things are not worth my Taking” (282).

\section{FAMILIAL ARRANGEMENTS}

In the instances quoted so far, most families consisted of a married couple with children. In some cases, the family had lost a parent and been augmented by people not related to the household head, such as a paid nurse. But in the standard classification of family forms suggested by Laslett, such

25. Peter King, "Pauper Inventories and the Material Lives of the Poor in the Eighteenth and Early Nineteenth Centuries", in Hitchcock et al., Chronicling Poverty, pp. 178-183.

26. See Paul Johnson, Saving and Spending: The Working-Class Economy in Britain 1870-1939 (Oxford, 1985), pp. 165-188.

27. Feinstein, "Pessimism Perpetuated", pp. 638-640. 
forms are also counted under the nuclear family. ${ }^{28}$ Complex family forms, however, are also in evidence in pauper letters. In fact, as these records reveal, there were often good reasons for poorer people to form co-resident groups extending beyond the "normal" family. This suggests that the widely accepted view, again first expressed by Laslett, according to which the nuclear family was particularly prevalent among the poor, may have to be reconsidered.

Perhaps the most typical form of an extended family household encountered in pauper letters is that where an unmarried women with an illegitimate child resided with her parents. An illegitimate child had a settlement in his or her own right, on the basis of which the mother could claim relief from the parish in which the child had been born, irrespective of her own settlement or that of her husband, in case she later got married to another man than the child's father. Living in with her parents thus had a double advantage. The grandparents, or more typically the grandmother, could look after the child when the young mother went out to work. At the same time, the parochial allowance for the child could benefit the entire household. Otherwise, that is when the mother lived on her own, the allowance might have to be used for putting the child out with other people to enable the mother to work.

Interestingly enough, the possible advantages for young single mothers of living with their parents were also seen by the overseers responsible for the relief of illegitimate children. The best documented cases are those where they shared the interest in the arrangement of such extended families in order to "push" such children to other places. Thus, early in 182I, the overseers of the parish of St Botolph in Colchester sent Hannah Watson and her newborn child to Shoreditch in London, where they were taken in by her parents. Her father, George Watson, sent a long letter to Colchester in which he fiercely protested against this - not because his daughter had been sent to him, but because she had been sent without previous notice. $\mathrm{He}$ also said "it Surprizes me that a woman with an Infant Child only 6 Weeks old and that In the middle of Winter should take such a Journey it is a Providence she has not Suffer.d Siverely for it". With respect to the household arrangement he pointed out that "if Sir she has House room with me it is as much as I can do for her she and her Infant is Sleeping along with 2 of my Girls on a very small bed I may say all of them Crippled". Having thus made his family's precarious situation clear, he went on to bargain:

My Daughter Informs me Sir you have Propos.d allowing her $4 \mathrm{~s}$ [= 2op] Per Week

28. Peter Laslett; "Introduction", in Peter Laslett and Richard Wall (eds), Housebold and Family in Past Time (Cambridge, 1972), pp. 23-44; E.A. Hammel and Peter Laslett, "Comparing Household Structure over Time and between Cultures”, Comparative Studies in Society and History, 16 (1974), pp. 73-109. 
with Respect I beg leave to say that she and the Child Cannot Subsist on it. she has tried it since she has been home it will Scarcely Procure her half support as she ought to have as a Woman Suckling a Child if Sir you will Please to allow her another Shilling she will be humbly thankfull (320).

Unfortunately, the parish records of St Botolph, Colchester, provide no clue as to whether George Watson's attempt at having the allowance for his grandchild increased was met with success. But it is clear that she did receive support during the following years. In May 1827, George Watson wrote again. His daughter and her child were still living with him, and he acknowledged that they had received 4 shillings per week. But that allowance had been reduced to 2 shillings (= IOp) and "a few Shillings Now and then" which he said was insufficient. He went on to point out that "if it was not for me she \& Child Must starve”, and concluded that they would have to return to St Botolph's parish in Colchester unless their allowance was increased to $256 \mathrm{~d}(=\mathrm{I2} .5 \mathrm{p})$ :

I donot wish to send her and Child down to you without first writeing to you and haveing yr awnswer but if it is your Pleasure not to do a Little More for her they Must Come down [...] if you would Please to allow her $6 \mathrm{~d}[=2.5 \mathrm{p}]$ a Week more and send her a few shillings to Gett herself and Child a few Nessasaries (352).

Typically enough, the allowance was increased by $6 \mathrm{~d}(=2.5 \mathrm{p})$, as is evident from his next letter of November 1827 , in which he again pleaded for some additional relief "to gett a few Nessasarys such as a Pr of shoes for herself and child a bit of Linnen and and a flanell Peticoat those are the things she wants" (359). Again, the next letter, sent a month later and signed in the names of both George and Hannah Watson, reveals that the request was met favourably (360). George Watson's further letters, stretching until July 1828, leave no doubt that his daughter and grandchild received regular support from Colchester $(368,372,373,376,378)$.

Arthur Tabrum received an allowance of $156 \mathrm{~d}(=7.5 \mathrm{p})$ per week for his stepson Arthur Good, the illegitimate child of his wife Ann (née Good). In this case, the self-confident tone in which he approached the overseers is particularly remarkable:

[...] whilst I Keep him I shall expect to be Paid for it, and If I do not receive any remuneration, I shall take him before the Lord Mayor, and see what is to be done, and whilst you make me keep him you are imposing upon a Man that is hardly able to support his own, it was the agreement of the Parish to allow the $r^{5} 6^{d}$ [ $7.5 \mathrm{p}]$ if I took him therefore I have a right to it [...] if the Parish Does not Pay me I shall put it into Court, as I have had advice about it [...] when I am keeping all the expense $i \mathrm{can}$ of the Parish and working hard for a Living, not to be assited in a small trifle more to maintain that I have no business to Do myself (I7I).

Elderly people are also reported to have lived with their married children or other kin who looked after them. Elizabeth Reilly wrote from Westminster to Rayleigh: 
[...] my Mother [...] is living with me and has done for sevn Years I have ben much Afflected and through that so many expenses which renders me incapable of keeping her any longer without Sum Allowance from her parish [...] She is now Eighty Years of age and very lame through one of her Legs being very bad [...] let me know what you Gentlemen will allow her or I must be under the painful necessity of sending her home to her Parish (662).

It is on similar lines that the forming of extended households was discussed, where people said they would be prepared to take in an elderly relative, but needed financial assistance. Thus, Elizabeth Philbrick wrote to Chelmsford:

I have Lived 38 years in the Parish of Wivenhoe and brought up a Famaly and paid Rates and Taxes till now I am 68 years old and am not able to do it no Longer I am now Oblight to Call on the Parish [...] I have a Daughter that will take me if you Gentlemen will be so good as to allow me something a week (269).

Similar suggestions were put to the overseers concerning the taking in or keeping of grown-up brothers and sisters $(390,409)$.

Without further research making fuller use of other parish records, it is impossible to say whether or not it was exceptional that parish officers gave financial support to such arrangements. However, the cases witnessed in pauper letters, which display the motives, interests and options of the various parties involved (the poor, their relatives and the parish officers), perhaps more clearly than most other records, strongly suggest that publiclyfunded domestic care of elderly paupers (and of helpless people) by their relatives was probably far more widespread than has hitherto been assumed. Many parish officers seem to have agreed when suggestions of that kind were put to them, since they knew only too well that communal support of private care at home incurred far lower costs than the institutional care of old people. ${ }^{29}$

This contention is further supported by cases in which the parish authorities supported the care of an elderly bedridden pauper by paying someone - be he or she a relative or not - to live with and look after the old person in his or her household. Ann Thudgett, who lived in the London parish of St Giles, was looked after by her niece. She had received a weekly allowance of $3 \mathrm{~s} 6 \mathrm{~d}$ (= 17.5p) from her home parish, Steeple Bumpstead, for some time, which was handed over to her (or to her niece?) by a contact man, a certain Mr Earl. But apparently the allowance had then been reduced, because when she wrote to her parish she asked for Mr Earl to be instructed to hand her the full amount of $3 s 6 \mathrm{~d}(=17.5 \mathrm{p})$ as before. This, she said, was what she needed,

[...] for I canot live hear and Starve as I am a Poor Oflic[t]ed woman and Cannot

29. For a thoughtful discussion of the provision for the elderly under the Old Poor Law, see Pat Thane, "Old People and Their Families in the English Past", in Martin Daunton (ed.), Charity, Self-Interest and Welfare in the English Past (London, 1996), pp. 113-138. 
work for my Living and likewise that my Nece has to dress and un dress me and has had for years gentelmen Mary Ann Page I am Ann Trudgett['s] Nese I have don for my poor oflic[t]ed old a[u]nt for years with your assistance I have Boarded lodg wash and Every other thing that Laid in my Pour for $6 \mathrm{~d}[=2.5 \mathrm{p}]$ per day (85).

This letter is also interesting with respect to the question of authorship and thus of the power of the poor to express themselves - which, as we have said, is by no means the same as the ability to write, but also includes the power to arrange for a letter to be written by someone else. Thus, the letter from Mary Ann Page begins by speaking in the person of her aunt Ann Thudgett, but then the narrative subject changes precisely at the point where the text turns to the niece. Reading it, one is tempted to imagine the situation in which it was written, with Mary Ann Page at first drawing up what Ann Thudgett told (or even dictated to?) her (or what she invoked her aunt to be saying where in fact she was writing it all by herself?), and then explicitly continuing in her own words.

All this is not to say that public assistance to the private care of elderly people was automatically given under the Old Poor Law. In fact, in the last case the issue was obviously a matter of debate between their relatives and the parish officers, since the overseers of Steeple Bumpstead were trying to withhold the allowance for the elderly lady (87). Yet even such cases sit somewhat uneasily with the notion of social isolation as a typical concomitant of poverty in old age, an idea that has become prominent in recent research on the history of poverty. Paul Slack, for instance, in his masterly survey of poverty in Tudor and Stuart England, has written to this effect: "A lonely old age was the lot of most of the labouring poor".$^{30}$ By contrast, pauper letters reveal cases in which elderly women in receipt of poor relief actually lived with their children, or conversely, that the children, as household heads, received assistance towards the keeping of their living-in relatives. And it is obvious that these cases support the suggestion long ago made by Hans Medick that the formation of complex households could be understood as a means for the labouring classes of redistributing poverty through the system of family and kinship - and, as we should add, with the assistance of the local welfare system..$^{31}$

Middle-class observers who showed themselves shocked that the poor had their care of parents and other elderly relatives publicly funded in this way and who denounced the "deficiencies of parental and filial affection" among

30. Paul Slack, Poverty and Policy in Tudor and Stuart England (London, 1988), p. 85.

31. Hans Medick, "The Proto-Industrial Family Economy: The Structural Function of Household and Family during the Transition from Peasant Society to Industrial Capitalism", Social History, I (1976), pp. 308-309. For a general discussion of the demographic implications of such household arrangements, see Sokoll, Household and Family Among the Poor, pp. 289-293; Richard Smith, "Charity, Self-Interest and Welfare: Reflections from Demographic and Family History", in Daunton, Charity, Self-Interest and Welfare, pp. 23-50. 
the labouring classes, ${ }^{32}$ should, of course, have known better. The simple truth is that most elderly people in poverty could hardly expect their children to support them, given the latter's responsibilities for their own offspring. The dilemma in which they found themselves was neatly expressed in 1810 by Rachel Shoregh in a letter from Bethnal Green: "my Children are all married and got familys which these dear times they have as much as they can do to support and therefore are not able to assist me" (397).

\section{STRATEGIC ARGUMENTS}

Pauper letters were written by people who, however much they might have been suffering from destitution and been driven into despair, still found a way to express their most pressing needs. In presenting their cases, they reveal intriguing details about their living conditions, their attitudes and their expectations. Because the accounts they give often extend beyond what would seem to be necessary or appropriate for the immediate purpose, the letters provide unique insights into their daily struggle for survival and even allow occasional glimpses into their private lives. In fact, it is perhaps such unintentional details more than anything else which are particularly rewarding in analysing the substantive record of pauper letters, as we have tried to show in the previous sections, focusing on the themes of work and trade, householding and familial arrangements.

However, as the examples quoted in the last section have shown particularly clearly, in people's effort to make a living, even the organization of the family could be a matter of negotiation with the overseers. In order to round off our discussion, it is therefore appropriate to leave those thematic fields and return to the specific bargaining position from which the poor formulated their letters. Looking at the evidence from that angle, the question is not so much what people put forward in presenting their case, as how they used the account of their case to posit a claim. We want to unravel their strategic considerations in the negotiation of relief.

The letter writers use a wide range of "speech" forms, each of which corresponds to a specific social habitus. Some invest apologetic phraseology and deferential rhetoric, others prefer simple statements in plain prose. Some utter a desperate outcry, while others engage in self-conscious protest. It is tempting, of course, to assume that certain forms were more successful in obtaining relief than others. But that assumption is misleading for two reasons. First, it is typical for many letter writers not to opt for one particular form of writing but rather to combine defensive with offensive gestures. Second, even if those pieces which are more or less clear-cut are compared with respect to the response they received from the overseers, there appears 
to be no consistent association. The modest request can be rejected, just as the most imposing demand may be granted.

What seems to be more promising here is to look once more at the strategic position in which people found themselves; or, more precisely, at the way in which that position was in itself used as an argument. As we have seen, pauper letters typically came from people who did in fact receive poor relief from their parish even though they resided in another parish. This put them in strong bargaining position. They knew that their removal was unlikely, because it would cause more trouble for their home parish (and for their host parish as well, which however need not concern us here) than the administration of nonresident relief.

The disadvantage of their "coming home" was indeed the key strategic argument in the negotiations with the overseers. It was brought forward in various forms. One form was to stress the better employment opportunities in the host parish, especially in cases where lack of work could be said to be only temporary. Thomas Cooper in Woolwich, for example, had fallen ill and asked the overseers,

[...] to send me a Present Relief or else I shall be Oblidge'd to Apply to the Overseers of Woolwich Parish and as soon as I get better be passed home which may be Avoiead as I hope to get better for I have work to do as soon as I am Able to do it and Possable I my shortly return to it again (138).

Sarah Withnell in Bethnal Green reported that:

[...] the Silk Weaven is So bad I can get but little Work at present I must give up My room and throw my Self upon the parrish to bring me and the Children home (which I should be greved to my hert to do for various Reasons) for as the Silk Weaven is expected to go much better In 2 or 3 months (287).

Elderly people felt that the question of employment was less important. George Rowe in Bocking pointed out that "to Leve the place will Not be No adwantage to you as I am Between 60 and 70 years of Age and I find I am Not fitt to Do Good Worke" (558). In this case, then, the argument was that it made no difference where people resided so that they might as well be left to stay in their host parish. Others took a more positive stance, stressing the psychological advantages of remaining in their familiar surroundings. William James in Chelmsford declared "I should wish to spend, the remainder of my Days, where I am, it cannot be long, E'r my head, must be laid in the dust" (484).

Another argument, which we have already encountered above in the case of David Rivenall and of other people, was not simply to point out the comparative advantages of living in the host parish over being removed but to threaten to "come home". Benjamin Brooker in Ipswich, put it succinctly: "And you May if you Please Send the ten Shillings Pr week as We Greatly Want it if you Do not think propper to Send it We Will Come home" 
(506). The argument could be made more powerful by referring to the expected high cost of relief at home. Mary Taylor in Hadleigh (Suffolk), the widow who was longing for a "peice of cloth to make my Children some shirts", was particularly explicit. The payment of her weekly allowance ("the money which is my due") of 4 shillings (= 20p) had been delayed several times, and if it were not sent regularly in future, she was "determined to come home into the [Poor]House". She went on: "then instead of paying me eight shillings a week you will have to pay four or five shillings a head for us". And as if this point were still insufficient, she declared that she had sought legal advice and ended her letter by referring to a court case at the Assizes in Bury St Edmunds where a pauper had won a similar case (322).

This letter is remarkable. The tone in which Mary Taylor addressed her parish (St Botolph in Colchester) is as self-confident as her arguments appear to be well-informed and well-founded. Admittedly, the reference to the legal case is not precise. But the estimate of the amount of indoor relief her parish would have to face after her return is probably pretty accurate. Unfortunately, there is no evidence on the costs of maintaining paupers within workhouses for the time when she wrote her letter (May 1821). But if we regard the nearest figure available (for 1802 ) as a reasonable secondbest, it appears that in the county of Essex weekly expenses for indoor relief did in fact amount to 5 shillings (=25p) per head. ${ }^{33}$ It looks as though the overseers of St Botolph were forced to accept her point. Precisely how much the total costs for the indoor relief of her family would have been is unknown, since the number of her dependent children is not given. But we do know that two months after her letter her regular allowance was increased to 8 shillings $(=40 \mathrm{O})$ per week. It was later again reduced, first to 6 shillings $(=30 \mathrm{p})$ and then to 4 shillings $(=20 \mathrm{p})$, but she received regular assistance at least until December 1826 (322).

Finally, there is the argument of the trouble involved in the procedure of removal itself. On 5 February 1824, Samuel Hearsum, in the London parish of St Marylebone, wrote to the overseers of Chelmsford:

According to promise I Expected a line from you before now to lit me Know Wether the Gent $t^{\mathrm{n}}$ of the Committee p[l]ease to allow me a small Trifle weekly, I think it very hard as I have payd so much into the poors fund to be Forsed in to the Workhouse for the Triflon sum of $\mathrm{r}^{\mathrm{s}}: 6^{\mathrm{d}}[=7.5 \mathrm{p}]$ per week, which I will Endevour to make shift with, Gentalmen If not I hope you will be so good as to let me know wether you would pay Mr French to bring me Down or to Appley to Marylebone Parish to Pass me home which will be very Expenceiv as I Am not Able to Walk

33. Parliamentary Papers, $1803-1804$, XII, Abstract of the Returns Relative to the Expense and Main-

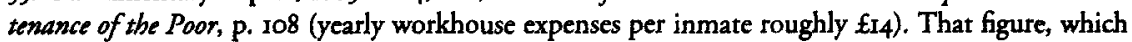
refers to 1802 , would appear to be a sound proxy, given that total poor relief expenditure in Essex (indoor plus outdoor relief) were roughly the same in both 1802 and 1821 , amounting to fo.8 per head (which was relatively low in the long run). See D.A. Baugh, "The Cost of Poor Relief in South-East England, 1790-1834", Economic History Review, 28 (1975), p. 56 (Fig. 3). 
I Almost killed my self when I Came Down last, and I never should have reached home If I had not meet with a Good Friend I send by Coach to save Expencess which I hope I shall have an Amswer by retrun of Coach and a few Shillings as I Am in great Distress.

The letter needs a little explanation. Apparently the overseers of Chelmsford had told Samuel Hearsum that they were no longer prepared to assist him in London and that if he wished further relief he would have to enter the workhouse in Chelmsford. In his response, he made three points. First, he showed himself amazed that there should be so much ado about an allowance amounting to the "trifling sum" of Is $6 \mathrm{~d}$. Second, he pointed out that as a parishioner of Chelmsford he used to pay poor rates when he had been better off, so that he now felt entitled to relief. Third, he made it clear that he was not prepared to "come home" voluntarily, which meant that his conveyance or removal was going to be a troublesome and expensive affair.

This case is particularly interesting when compared to those encountered so far. Unlike Susan Pitt or Mary Taylor, Samuel Hearsum did not even insinuate that he could ever make positive use of the workhouse. He simply loathed it, and was shocked that he might be subjected to what came to be known as the "workhouse test" under the New Poor Law. Next, Mr French, the man mentioned in the middle of the letter, was that coachman travelling between Chelmsford and London who handed out the allowances to the Rivenalls and several other Chelmsford paupers living in London. And finally, on his journey to London in December 1823, on behalf of the select vestry of Chelmsford, John Sheppee had not only visited the Rivenalls, but also called on Samuel Hearsum. According to Sheppee's report, Hearsum was then aged $7 \mathrm{I}$ and sold tea on commission which brought him 6 shillings (= 30p) per week. But his rent alone was $2 s 6 \mathrm{~d}(=\mathrm{I} s \mathrm{p})$ per week, and he was indebted with $£_{I I}$ to his former master. He used the allowance he received from Chelmsford to repay his debt. Sheppee gives a vivid account of their conversation: "I told him that as I did not consider that the Parish of Chelmsford were bound to pay his debts, no further allowance would be given him. - his answer was "Then I must come down'". As a matter of fact, Samuel Hearsum does not seem ever to have turned up in Chelmsford. He did not have to, since his relief was continued. However, this was not or rather, not only - the result of his threat to "come down" as expressed in that conversation and then again in his letter sent two months later. For what he did not know is that Sheppee, on his part, had closed his report to the select vestry with the telling remark: "from appearances I think is/ [ $=5 \mathrm{p}] \mathrm{pr}$ week would prevent him from coming home" (ro).

This assessment is exceptionally explicit. But otherwise there is nothing special about it. For the irony that Hearsum must have thought that he had got his own way against the parish officers of Chelmsford, where in fact he had only kicked at an open door, does not mean that they had won the day. On the contrary, it underlines the point on which our entire discussion has 
been based, namely that pauper letters have emerged from cases in which the host parish and the home parish basically shared the pauper's interest in not being removed. Pauper letters need not only to be seen in that context - they are in themselves part of that particular situation. In particular cases, it might even be said that this peculiar convergence of interests led to a balance of forces between the overseers on the one hand and the pauper on the other.

Whether or not one wants to go as far as this, the conclusion seems plausible that the poor had considerable room for strategic manoeuvring. The Old Poor Law was not only a measure of social control. It also provided an institutional platform on which the labouring poor could effectively express their needs, pursue their interests and establish their claims. ${ }^{34}$ This was not least the understanding of the Poor Law by the poor themselves, of which pauper letters probably provide the richest record of all. These letters remind us that poverty is not a condition but a social relationship. The poor are always forced to extreme efforts to make a living. But there are historical situations where they possess the opportunity, at least to some extent, to negotiate a living. 